\title{
REVIEW \\ Michael S. Kogan \\ Opening the Covenant: A Jewish Theology of Christianity
}

New York: Oxford University Press, 2008. Hardcover, xiv + 284 pp.

Reviewed by Franklin Sherman, Muhlenberg College (emeritus)

This is a significant volume by Michael Kogan, Professor of Religious Studies and Director of the Jewish American Studies program at Montclair State University (New Jersey). Kogan credits John Pawlikowski with inspiring him to write a "Jewish theology of Christianity" comparable to the "Christian theology of Judaism" propounded by scholars like Clemens Thoma. That is to say, just as Christian scholars have asked themselves, "What is the significance of the ongoing vitality of Judaism within the Christian scheme of things?" Jewish scholars should ask themselves, "What is the significance of the ongoing vitality of Christianity within the Jewish scheme of things?"

Kogan's broad answer is: Christianity (meaning the story and message of Jesus and his interpreters, especially Paul, as well as the ongoing history of the Christian movement) has served to "open the covenant" to the gentiles, making the benefits of that covenant-God's grace and guidance-available to all who choose to enter it. Those who become Christians do not thereby become Jews; Judaism remains a unique peoplehood and practice. But they do become "Israelites," worshipers of the God of Israel as part of the Israel of God.

Kogan intends this as a much stronger statement than Maimonides' acknowledgment that Christianity has served to bring knowledge of Torah to the nations. He is willing to view the "Christ event" (using this Christian term) as in some sense revelatory, and as a new act of God. Jesus is not a "failed messiah," as Irving Greenberg would have it, but in fact succeeded-again, with the aid of Paul and his other interpreters-in opening the covenant to the Gentiles, thus enabling Israel to fulfill its prophetic goal of serving as a light to the nations.

Kogan is not working with a reduced understanding of Christianity; he takes it at full strength. Thus at one point he asks himself and the reader, "What are the central propositions of the Christian faith?" He lists them as follows (p. 114):

1. The incarnation of God in Jesus;

2. The vicarious sacrifice of Jesus for the sins of the world;

3. The resurrection of Jesus from the dead.

Kogan makes clear: we Jews do not believe in any of these propositions-but we need not decry them as irrational or idolatrous. This is the symbol system that has conveyed the knowledge of Israel's God to the nations, and all of these propositions are, in fact, Jewishly understandable. On the possibility of incarnation, he cites certain stories in the Hebrew Scriptures of the appearance of God in human form, but more generally, appeals to Michael Wyschogrod's theme of "corporeality" in his The Body of Faith: God in the People Israel (San Francisco: Harper \& Row, 1983). On vicarious atonement, he refers to Isaiah 53-a Jewish source, after all. As to resurrection: this was a fundamental Jewish doctrine, affirmed especially by the Pharisees, and has been part of the Jewish eschatological hope down through the centuries. Thus it was not and is not a preposterous notion, from a Jewish standpoint. Whether someone was actually raised from the dead at a given point in history is another question. 
So: these things are believe-able, even if in fact one does not believe them (my own formulation). It is no accident that Kogan refers to Kierkegaard at this point. He teaches courses on Kierkegaard, and is working here with the latter's concept of faith as "an objective uncertainty, held fast through appropriation with the most passionate inwardness." Thus the Jew can understand and in some way identify with the Christian's faith-affirmations, even while not joining in them.

Kogan reviews the work of recent as well as more remote contributors to a Jewish theology of Christianity. Rabbi Menachem Ha Me'iri, of 13th/14th-century Provence, offered a positive evaluation of both Christianity and Islam as "nations restricted by the ways of religion," and hence not comparable to the idolaters of old. Moses Mendelssohn, in the age of Enlightenment, developed a "religious pluralism coupled...to an ethical universalism," as Kogan puts it. Elijah Benamozegh (1823-1900), rabbi of Leghorn (Livorno), Italy, saw Judaism and Christianity as sisters. "If they are fundamentally united and interdependent, no power on earth will be able to separate them permanently," he wrote. "Indeed, to the contrary, they will know at the proper moment how to join their energies of spirit and intelligence" (Israel and Humanity, transl. Maxwell Luria, New York: Paulist, 1995 ["Classics of Western Spirituality" series], p. 51).

As to more recent figures, Kogan appreciates and, it would seem, translates into his own terms Franz Rosenzweig's striking image of Judaism as the "eternal flame" at the heart of the Star of Redemption and Christianity as the "eternal rays" streaming out to the world. He rejects, however, Rosenzweig's view of Judaism as essentially unworldly, seeing him as influenced too much by the nature of Jewish life in the shtetls and ghettos of Eastern Europe rather than the role of Jews in Western Europe and America, and even more their "return to history" in the State of Israel. Kogan is closer to the view of Buber, who sees the Jews as firmly this-worldly, while Christianity is more unworldly. Kogan believes, however, that in these and other such comparisons-Christianity as individualistic, Judaism as communal; Christianity as based on pistis (belief), Judaism on emunah (trust)-Buber has oversimplified and to some extent stereotyped the Christian dialogue partner.

Regarding Heschel, Kogan notes that his context in a pluralistic America and his experience of working side by side with Christians in the public sphere enabled him to feel close enough to Christians to be a loving critic of their faith, as he was of Jews and Judaism. He called on both faith traditions to resist the trivialization of religion, following instead in the bold tradition of the Hebrew prophets. Kogan faults Heschel, however, for failing to deal directly with the significance of Jesus, as Buber had done. As to his elder contemporary Irving Greenberg, Kogan sees him as a colleague in the task of opening up Jews to a more sympathetic understanding of Christianity. As noted above, however, he objects to Greenberg's conception of Jesus as a "failed Messiah," finding this unnecessarily demeaning to Christians, and not reflective of the complexity of messianic concepts in Jesus' time. A failed what-kind-of-Messiah? Kogan devotes a full chapter to tracing the various types of messianic thought in the Hebrew Scriptures and in later Jewish writings.

Under the title "The Forty Years' Peace," Kogan reviews the development of Christian-Jewish relations during recent decades as it can be traced in the plethora of Christian statements on the subject. He devotes almost all of his attention to Roman Catholic documents, however, taking note of only a few of the many similar Protestant statements, some of which long antedate Vatican II. Kogan also offers brief comments on the thought of individual scholars in this field: Paul van Buren, A. Roy Eckardt, Clark Williamson, and John Pawlikowski. Kogan urges such 
Christian interlocutors not to present a trimmed-down version of their own faith, nor to idealize Jewry.

Kogan shows a real familiarity with the Christian vernacular, as expressed in preaching and liturgy as well as theology; he characterizes himself as "a frequent visitor to church services." He devotes a chapter to recounting some of his experiences of teaching about Judaism in Christian churches and about Christianity in Jewish synagogues, as well as in interfaith venues. He reviews the pivotal statement "Dabru Emet" and the Christians Scholars Group's response, "A Sacred Obligation," as well as the controverted "Reflections on Covenant and Mission." Surprisingly, however, he does not deal with the important volume produced as a follow-up to Dabru Emet by Tikva Frymer-Kensky, David Novak et al., Christianity in Jewish Terms (Boulder: Westview, 2000).

Kogan's book gives evidence of some of the chapters having originated as separate lectures or journal articles-the basics of how far the dialogue has come, etc., are repeated frequently-but this need not be a hindrance to the reader. This is a book that should be taken account of by all, whether Christian or Jewish or other, who are working in this field of the encounter of living faiths. 